\title{
STRATEGI KOMUNIKASI LEMBAGA AMIL ZAKAT \\ NURUL FIKRI ZAKAT CENTER DALAM UPAYA PENGHIMPUNAN DANA UMAT DI KALIMANTAN TENGAH
}

\author{
Adi Cahyono \\ e-mail: cahyonoadi64@gmail.com \\ Universitas Islam Kalimantan MAB Banjarmasin
}

\begin{abstract}
The management of zakat essentially covers the purposes and usefulness of communication. An informative, persuasive and entertained zakat message provides a person with the potential for zakah to believe it is an obligation. Furthermore, the sense of confidence that makes them stirred to practice and with pleasure and feel secure after the zakat fulfilled. The problems raised in this research are: 1) How is the communication strategy used by NF Zakat Center in collecting zakat in Central Kalimantan, then the next issue 2) How marketing activities conducted by NF Zakat Center, and 3) How NF Zakat Center utilize zakat to the mustahik. This type of research is a qualitative research conducted in two stages of preliminary research and advanced research. The data source of the researchers comes from a collection of NF Zakat Center archives. Data collection methods used were in-depth interviews, observation and documentation. Furthermore, data management techniques and data analysis is done to answer the questions.

The results of this study indicate that the communication strategy implemented by NF Zakat Center in the effort to collect the funds of the people in the form of zakat, infaq and charity is through interpersonal communication in order to foster good relationship with muzakki, candidate muzakki and the mustahik. NF Zakat Center maximizes the collection efforts through online and online marketing activities by regularly to visit each others and utilizing social media channels. The programs and activities of empowerment in strategic and targeted areas have a positive impact in supporting the efforts of raising people's funds by the NF Zakat Center in Central Kalimantan.
\end{abstract}

\section{Keywords: Communication Strategics and Zakat}

\section{PENDAHULUAN}

Bagi muslim dan muslimah, menunaikan zakat merupakan ibadah dan kewajiban sebagaimana yang termaktub dalam Al-Qur'an surah AtTaubah ayat 103. Sementara itu untuk menggarap tugas-tugas pemungutan, pengumpulan, pemeliharaan, pencatatan, dan pembagian zakat menjadi tanggungjawab amil melalui badan/lembaga amil zakat sesuai pesan yang terkandung dalam Undang-undang Nomor 23 Tahun 2011 tentang Pengelolaan Zakat. 
Mengelola zakat adalah kegiatankegiatan komunikasi interpersonal yang pada hakekatnya mencakup ketiga tujuan-tujuan dan kegunaan terselenggaranya komunikasi. Pesan zakat memberikan yang berpotensi untuk berzakat menjadi meyakini itu suatu kewajiban. Menjadikan mereka tergugah untuk mengamalkan serta dengan senang hati dan menjadi aman setelah zakat terpenuhi. Mengelola zakat berarti pula sebagai kegiatan berkomunikasi dalam kesatuan unsur dalam proses yang telah dikemukakan oleh Harold D. Laswell. Satu kesatuan kegiatan komunikasi pada NF Zakat Center diantaranya orang (muslimin dan muslimah) yang berpotensi berzakat dan yang telah berzakat (muzakki) dan orang-orang yang berhak menerima zakat (mustahik/asnaf zakat)

Dalam penelitian ini bertujuan untuk mengkaji bagaimana strategi komunikasi lembaga amil zakat Nurul Fikti Zakat Center dalam upaya penghimpunan dana umat di Kalimantan Selatan.

\section{TINJAUAN TEORITIS}

Penelitian ini pada hakekatnya adalah tentang bagaimana efektivitas komunikasi pada penglolaan zakat di Kalimantan Tengah yang dijalankan oleh
NF Zakat Center. Indikasi efektivitas komunikasi pada penelitian ini dibatasi hanya pada Bagaimana strategi komunikasi yang digunakan oleh NF Zakat Center dalam menghimpun zakat, bagaimana kegiatan marketing dan aktivitas mendayagunakan zakat kepada yang berhak (mustahik) oleh NF Zakat Center.

Pengelolaan zakat oleh amil zakat telah dicontohkan sejak zaman Rasulullah Shallalahu 'alaihi wassallam dan para khulafa' ar-Rasyidin. Salah satu contohnya adalah ketika Nabi Muhammad Shallalahu 'alaihi wassallam mengutus Muadz bin Jabal ke Yaman dan pada saat beliau menjadi Gubernur Yaman, beliau pun memungut zakat dari rakyat dan disini beliau bertindak sebagai amil zakat. Rasulullah SAW mencontohkan tata cara mengelola zakat agar tujuan dan maksud mulianya dapat terwujud, yakni dengan mengelola dan mendayagunakan zakat secara melembaga dan terstruktur dengan baik. Hal inilah yang kemudian menjadi dasar berdirinya berbagai Lembaga Amil Zakat di berbagai negara, termasuk di Indonesia khususnya di Kalimantan Tengah.

Sejak 1999 pengelolaan zakat di Indonesia memiliki dasar hukum yaitu 
berdasarkan UU No. 38/1999 tentang

Pengelolaan Zakat; Keputusan Menteri

Agama RI No. 373 Tahun 2003 tentang

Pelaksanaan UU No. 38/1999;

Keputusan Dirjen Bimas Islam dan

Urusan Haji No. D/291 Tahun 2000

tentang Pedoman Teknis Pengelolaan

Zakat dan yang paling baru yaitu

Undang-undang Nomor 23 Tahun 2011

tentang Pengelolaan Zakat.

\section{METODOLOGI}

Penelitian ini adalah penelitian kualitatif. Penelitian dilakukan dalam dua tahapan yaitu didahului dengan Penelitian Pendahuluan yang dilanjutkan dengan Penelitian (lanjutan). Penelitian pendahuluan ditujukan untuk menguji kuesioner agar diperoleh kuesioner yang sesuai dengan tujuan-tujuan pada penelitian. Persiapan dan penelitian diselenggarakan di lingkungan NF Zakat Center, dimulai pada bulan Januari sampai dengan April 2018 sesuai rencana alokasi jadwal dan waktu yang telah ditentukan.

Penetapan informan dilakukan dengan teknik pilihan sengaja (purposive sampling) dengan populasi yang berasal dari tiga kelompok yang berkaitan, yaitu yang telah mengeluarkan zakatnya (Muzakki), yang berpotensi berzakat, petugas/ manajemen pada NF Zakat
Center (Amil) dan Penerima zakat (Mustahik/ Asnaf zakat).

Dalam hal pengumpulan data pada penelitian teknik yang digunakan dalam penelitian ini adalah wawancara, observasi dan dokumentasi. Pada penelitian ini, peneliti menganalisis hasil wawancara berdasarkan pemahaman terhadap hal-hal diungkapkan oleh responden. Data yang telah dikelompokan tersebut oleh peneliti dicoba untuk dipahami secara utuh dan ditemukan tema-tema penting serta kata kuncinya. Setelah kategori pola data tergambar dengan jelas, peneliti menguji data tersebut terhadap asumsi yang dikembangkan dalam penelitian ini. Pada tahap ini kategori yang telah didapat melalui analisis ditinjau kemabali berdasarkan landasan teori yang telah dijabarkan.

Dalam penelitian ini penulisan yang dipakai adalah presentase data yang didapat yaitu dari hasil penelitian berdasarkan wawancara mendalam dan observasi. Proses dimulai dari data-data yang diperoleh, dibaca berulang kali sehinggga penulis mengerti benar permasalahanya, kemudian dianalisis, sehingga didapat gambaran mengenai penghayatan pengalaman dari subjek. Selanjutnya dilakukan interprestasi 
secara keseluruhan, dimana di dalamnya mencakup keseluruhan kesimpulan dari hasil penelitian.

\section{PEMBAHASAN}

Pengentasan keterpurukan hidup kaum dhuafa menjadi ruh yang menjiwai NF Zakat Center sejak awal dirintisnya pada November tahun 2011. Aktivitas meningkatkan nilai guna zakat, infaq dan shadaqah melalui program peningkatan kualitas sumber daya manusia dan pemberdayaan ekonomi produktif menjadi prioritas prestasi yang ditekankan oleh lembaga. Selain itu juga menjadi fokus perhatian pada bidangbidang lain seperti keagamaan, kesehatan dan sosial kemanusiaan.

NF Zakat Center adalah lembaga zakat, infak dan sedekah yang bernaung di bawah Yayasan Nurul Fikri Palangka Raya dengan legalitas yang lengkap sebagai lembaga penghimpun dana umat. Adapun legalitas-legalitas yang telah dipenuhi diantaranya:

1. Ijin Operasional oleh Dirjen Bimas Islam Kemenag RI SK. 941 Tahun 2017;

\section{Rekomendasi BAZNAS Nomor} 093/SET.BAZNAS/01.02/X/2017;

3. Terdaftar di Kesbangpol Provinsi Kalimantan Tengah, Nomor: 00-1100/7/III/2016;
4. Terdaftar di Kesbangpol Kota Palangka Raya, Nomor: 300.3.2/552/BKBP/2015;

5. Akta Pendirian No. 20 Tanggal 17 Januari 2017 oleh R.A.Setiyo Hidayati, SH dan SK Menteri Hukum dan Hak Asasi Manusia Republik Indonesia Nomor: $\mathrm{AH}$ 0000115.AH.01.05.TAHUN.2017;

6. Surat Keterangan Terdaftar pada Direktorat Jenderal Pajak Departemen Keuangan Republik Indonesia No : PEM-272/WPJ.209/KP.0303/2007.

Sebagai sebuah lembaga yang berkepentingan dalam tugas menghimpun dan mendayagunakan dana umat NF Zakat Center memiliki visi dan misi yang saling berhubungan untuk menciptakan sebuah kondisi dimana masyarakat dapat lebih peduli dan sadar terhadap kewajiban berzakat untuk menciptakan kemandiriankemandirian umat secara bersama-sama dengan tata kelola yang amanah dan professional.

Sejak didirikan pada 2011 dalam upaya penghimpunan, setiap tahun kepercayaan masyarakat terhadap $\mathrm{NF}$ Zakat Center juga terus meningkat. pengalaman kerjasamapun banyak yang sudah dilakoni dengan berbagai lembaga baik instansi pemerintahan, BUMN, 
perbankan dan dengan sesama lembaga nirlaba maupun dengan perorangan. Hal tersebut tidak terlepas dari upaya amil menjalin hubungan melalui komunikasi efektif yang ditunjang dengan transparansi, akuntabilitas hingga penggunaan sarana teknologi modern dan media. Namun dalam sisi angka, penghimpunan NF Zakat Center masih jauh dari angka potensi zakat di Kalteng yang mencapai 25 milyar rupiah pertahunnya menurut Badan Amil Zakat Daerah (BAZDA) Kalimantan Tengah (Anonim, 2012).

Tujuan dalam pelaksanaan penelitian ini adalah 1) untuk mengetahui strategi komunikasi yang digunakan oleh NF Zakat Center dalam menghimpun zakat di Kalimantan Tengah, 2) Untuk mengetahui kegiatan marketing NF Zakat Center dalam menghimpun zakat di Kalimantan Tengah dan selanjutnya 3) yaitu untuk mengetahui seperti apa NF Zakat Center mendayagunakan zakat yang dikelola kepada para mustahik.

Penelitian dilakukan terhadap satu kesatuan unsur komunikasi NF Zakat Center dimana terdapat 4 (empat) kategori susunan panduan wawancara (interview guidline) dari 4 (empat) kelompok informan untuk menjawab rumusan masalah yang hasilnya sesuai dengan tujuan-tujuan penelitian diantaranya 1) yang telah mengeluarkan zakatnya (Muzakki ), 2) yang berpotensi berzakat melalui NF Zakat Center, 3)petugas/ manajemen pada Lembaga Amil zakat Nurul Fikri Zakat Center, dan 4) penerima zakat ( Mustahik/ Asnaf zakat ).

Kategori 1, 2 dan 3 masing-masing 3 (tiga) Informan sehingga berjumlah 9 (sembilan orang). Pada kategori penerima zakat sebanyak 2 (dua) informan, masing-masing mewakili satu orang penerima zakat melalui program konsumtif dan pemberdayaan.

Hasil penelitian berdasarkan data dan informasi yang diperoleh dilapangan dan diolah diantaranya:

1. NF Zakat Center memiliki unit layanan pada 4 area se-Kalimantan Tengah yaitu di kota Palangka Raya, Sampit, Pangkalan Bun dan Kapuas. Masing-masing memiliki cakupan wilayah kerja.

2. NF Zakat Center memiliki layanan jemput donasi, zakat, infaq dan sedekah untuk membantu para muzakki dalam menunaikan kewajiban dan kepeduliannya terhadap sesama. 
3. NF Zakat Center memiliki programprogram yang mencakup aspekaspek kebutuhan vital seperti kesehatan, ekonomi, pendidikan, keagamaan dan kemanusiaan.

4. Program-program NF Zakat Center memiliki daya tarik yang mampu menjadi magnet bagi para muzakki untuk terus rutin menunaikan kewajiban dan kepeduliannya melalui lembaga tersebut.

5. Para muzakki NF Zakat Center menginginkan untuk dilibatkan dalam aktivitas pendistribusian bantuan. Sebagian kecil sudah terpenuhi dengan menjadikan mereka sebagai perpanjangan tangan dalam pengembangannya.

6. Amil NF Zakat center rutin melakukan silaturrahmi dan memperluas channel namun belum secara menyeluruh menyentuh masyarakat khususnya yang berpotensi.

7. NF Zakat center memanfaatkan media sosial untuk mengeksplor informasi kegiatan-kegiatan yang dilaksanakan dalam kesatuan dengan pendekatan informal.

8. Feedaback berupa laporan keuangan dan kegiatan rutin diberikan oleh NF Zakat Center kepada para muzakki setiap bulan. Secara isidentil juga diinformasikan manakala ada muzakki yang ingin tahu diluar rutinitas.

9. Setelah menunaikan zakat, infak dan sedekah para muzakki mendapatkan respon berupa SMS pemberitahuan (notification)

10. Sebagian Aparatur Sipil Negara zakatnya sudah dikelola secara terpusat oleh negara melalui Baznas

11. Lembaga amil zakat masjid masih menjadi pilihan bagi sebagian masyarakat yang rumahnya dekat dekat dengan masjid

12. Wawasan tentang zakat walaupun sudah banyak kemajuan, pada sebagian masyarakat yang potensial masih belum up to date.

Hasil penelitian menunjukkan bahwa strategi komunikasi yang dilakukan oleh NF Zakat Center dalam menghimpun dana umat adalah dengan melalui komunikasi interpersonal yakni melalui silaturrahmi baik secara formal maupun informal. Suksesi strategi komunikasi tersebut dijalankan ialah dengan memasifkan aktivitas marketing online dan offline memanfaatkan konten pendayagunaan zakat. Konten berbentuk dokumentasi aktivitas pendayagunaan 
Volume 4 Nomor 1, April 2018

maupun laporan keuangan pasca mendayagunakan dana zakat diolah dan disajikan kepada para muzakki dan masyarakat luas khususnya orang-orang yang berpotensi untuk berzakat.

$$
\text { Pengelolaan zakat pada }
$$
hakekatnya mencakup ketiga tujuantujuan dan kegunaan terselenggaranya komunikasi (informatif, persuasif dan entertainment), seperti yang dikemukakan oleh David K Berlo. Pesan zakat memberikan yang berpotensi untuk berzakat menjadi meyakini itu suatu kewajiban. Menjadikan mereka tergugah untuk mengamalkan serta dengan senang hati dan menjadi aman setelah zakat terpenuhi.

Masyarakat muslim Kalimantan Tengah (Kalteng) yang di representasikan melalui informan penelitian meyakini bahwa kewajiban menunaikan zakat adalah hal yang penting. Namun dalam realisasinya aktivitas berzakat yang dilakukan oleh masing-masing orang berbeda-beda. Kecendrungan untuk tidak menyalurkan zakat melalui lembaga amil zakat didasari oleh sikap kritis terhadap pengelolaan dana umat oleh lembagalembaga sosial, belum terinformasikannya edukasi tentang fatwa zakat kontemporer dan keutamaan menunaikan zakat melalui lembaga amil seperti yang dicontohkan Rasulullah SAW serta kepercayaan untuk menyalurkan secara langsung zakat, infaq dan sedekah kepada objek penerima manfaat yang berada dekat disekitar muzakki.

Komunikasi interpersonal yang dilakukan amil NF Zakat Center selain bertujuan untuk menginformasikan pengelolaan dana umat didalam lembaga, lebih jauh lagi yakni membangun hubungan untuk memberikan rasa nyaman kepada para muzakki sehingga terus mempercayakan zakatnya pada Nurul Fikri Zakat Center, serta terus mengedukasi masyarakat yang berpotensi bahwasannya zakat adalah sebuah kewajiban yang harus ditunaikan jika muslim/ah telah memiliki harta yang mencapai nishab maupun haulnya dengan aktivitas-aktivitas yang memunculkan kesadaran dan menggugah orang untuk mengamalkannya.

Keberadaan NF Zakat Center disadari sebagai sebuah lembaga penghimpun dana-dana umat ditengahtengah masyarakat khususnya di Kalteng. Namun dengan keterbatasan jumlah amil dalam cakupan wilayah kerja, pesan zakat belum seluruhnya mampu terkelola/tersampaikan melalui 
Volume 4 Nomor 1, April 2018

edukasi dan sosialisasi kepada orang lain yang diharapkan dapat tergerak untuk mengamalkannya.

Muzakki yang rutin menunaikan zakat di NF Zakat Center tergerak berzakat melalui lembaga tersebut setelah diedukasi oleh amil saat bersilaturrahmi baik terkait ilmu perzakatan, informasi pelayanan dan menu program pendayagunaan zakat yang tersedia pada lembaga. Aktivitas NF Zakat Center dengan memanfaatkan media sosial sebagai sarana berkomunikasi dengan konten informasi pendayagunaan zakat menguatkan eksistensi dan hubungan dengan muzakki yang rutin berzakat pada lembaga, namun belum membuat orangorang yang berpotensi tergerak memutuskan untuk rutin berzakat pada lembaga tersebut.

\section{KESIMPULAN}

1. Strategi Komunikasi

a. Strategi komunikasi yang diterapkan NF Zakat Center dalam upaya penghimpunan dana umat berupa zakat, infaq dan sedekah adalah dengan menggunakan teknik komunikasi interpersonal guna membina hubungan baik dengan muzakki, calon muzakki dan para mustahik.

b. Eksistensi NF Zakat Center diketahui khalayak luas melalui aktivitas silaturrahmi amil, informasi mulut kemulut dan letak lokasi kantor yang strategis berada pada jalan-jalan utama.

c. Muzakki sangat terkesan dan terbantu dengan layanan jemput zakat/donasi yang sigap dalam mengingatkan dan tanggap dalam melayani karena memudahkan bagi mereka yang aktivitasnya padat dan sibuk.

d. Kendala dan tantangan yang harus dihadapi NF Zakat Center dalam mencapai target penghimpunan adalah wawasan zakat pada sebagian masyarakat masih rendah, pemahaman bahwa zakat sebaiknya langsung diserahkan pada yang berhak menerima, kepercayaan kepada lembaga amil zakat masih setengah-setengah dan kondisi ekonomi yang kurang stabil.

e. Kapasitas SDM pengelola lembaga yaitu amil terutama dalam hal berkomunikasi masih sangat banyak keterbatasan 
f. Kuantitas SDM tidak sebanding dengan luasan wilayah kerja

2. Aktivitas marketing

a. NF Zakat Center memaksimalkan kegiatan marketing secara ofline dan online yaitu dengan rutin bersilaturrahmi dan memanfaatkan kanal media sosial

b. Melalui kegiatan edukasi NF Zakat Center malakukan upaya menumbuhkan kesadaran dan ketaatan untuk berzakat, infaq dan sedekah

c. Para amil memiliki sarana pendukung yang senantiasa disiapkan berupa brosur, spanduk, proposal, laporanlaporan kegiatan maupun keuangan dan berbagai bentuk pendukung lainnya

d. Meluaskan channel dan memperbanyak mitra dengan memberikan penawaran yang saling memberikan dampak positif

e. Menjaga komunikasi sehat dan memberikan feedback berupa laporan-laporan keuangan maupun kegiatan

f. Melaksanakan kegiatan-kegiatan guna mencapai target sesuai dengan yang terkandung dalam
Rencana Kerja dan Anggaran Tahunan (RKAT)

3. Aktivitas Pendayagunaan

a. Program-program pendayagunaan zakat pada NF Zakat Center mencakup aspekaspek seperti kesehatan, keagamaan, kebencanaan, pendidikan dan ekonomi

b. Program-program pendayagunaan NF Zakat Center yang variatif menarik minat muzakki untuk berzakat, infaq dan sedekah dan memutuskan merutinkan diri untuk selalu menunaikan ibadahnya tersebut melalui NF Zakat Center

c. NF Zakat Center tidak memberikan perlakuan yang sama kepada setiap mustahik dimana ada yang diberikan pendampingan setelah menerima distribusi bantuan dan ada yang dibiarkan begitu saja setelah diberikan bantuan.

d. Dalam prosesi survey dan verifikasi calon penerima manfaat pendistribusian bantuan, kelengkapan administrasi standar masih belum dilaksanakan sepenuhnya. 
e. Pendampingan yang diberikan NF Zakat Center tidak hanya berupa keterampilan namun juga peningkatan keimanan dan taqwa kepada Allah SWT.

f. Jenis bantuan yang didistribusikan kepada mustahik benar-benar tepat sasaran karena melalui berbagai tahapan-tahapan verifikasi faktual, sesuai kebutuhan dan diterima secara langsung oleh mustahik.

\section{A. Saran}

1. Memberlakukan syarat administrasi yang sama bagi seluruh calon penerima manfaat distribusi bantuan

2. Memberlakukan pendampingan kepada setiap mustahik yang telah menerima bantuan sesuai kondisi dan kebutuhan dilapangan

3. Membuat alternatif program distribusi yang kreatif, mampu meningkatkan keterampilan mustahik dan daya ekonomi nya

4. Melibatkan muzakki dalam kegiatan pendistribusian bantuan baik dengan formalitas undangan ataupun mengajak serta untuk berpartisipasi secara langsung
5. Mempertahankan layanan jemput zakat, infaq dan sedekah

6. Mengikutsertakan amil dalam kegiatan pengembangan kapasitas pengetahuan perzakatan, pengelolaan organisasi/lembaga dan keterampilan komunikasi

\section{DAFTAR PUSTAKA}

Abdul Ghofur Anshori, Hukum dan Pemberdayaan Zakat Upaya Sinergis Wajib Zakat dan Pajak di Indonesia .Yogyakarta: Nuansa Aksara, 2006.

Ahmad Azhar Basyir, Hukum Zakat, cet. I, Yogyakarta: Majelis Pustaka Pimpinan Pusat Muhammadiyah, 1997.

Anonim. 2002. Pedoman Zakat, Departemen Agama RI Jakarta: Proyek Peningkatan Zakat dan Wakaf, 2002.

Anonim. 2011. Undang-undang Republik Indonesia No : 23 Tahun 2011 tentang Pengelolaan Zakat, Departemen Agama RI Jakarta, 2011.

Anonim. 1997. The Encyclopedia Americana. International Edition. American Corporation. International Headquarters: 575 Lexington Avenue, New York. 10022 
Babbie, Earl R. 1979. The Practice of Sosial Research. Belmont Wadsworth. California.

Basrowi, Suwandi, Memahami Penelitian Kualitatif, Jakarta : Rineka Cipta, 2008

Batey, Mark, Brand Meaning, New York: Routledge, 2008.

Berelson, Bernard and Garry A Steiner. 1979. Communication and Transmission of Information. Cambridge University Press. Massachussetts. Third Edition.

Berger, C. R, 2005. Communication and Social Processes. Newbury Park, California. Sage.

Berlo, David K. 1991. The Process of Communication. An Introduction to Theory and Practice.

Creswell, John W. 1998. Qualitative Inquiry and Research Design. Sage Publication, Inc. California.

Echols, John M and Shadily, Hasan. 1979 Kamus Inggris Indonesia. Cornel University Press. Ithaca and London. PT. Gramedia. Jakarta.

Fajar, Marhaeni. 2009. Ilmu Komunikasi Teori dan Praktik. Jakarta Barat. Graha Ilmu.

Fakhruddin, Fiqh dan Manajemen Zakat di Indonesia, Malang: UIN Malang Press, 2008.

Gamble, Michael W and Teri Kwal Gamble. 1986. Introduction of Mass Communication. McGraw-
Hill Book Co. New York. Third Edition.

Grant, John, The Brand Innovation Manifesto England: John Wiley \& Sons Ltd, 2006.

Grounlund, Norman E. 1975. Reading In Measurement and Evaluation. The Macmillan Company. Colier-Macmillan Limited. London. The 4th Edition.

Guba, E.G. and Y.S. Lincoln. 1990. Effective Evaluation. Jossey Bass Publication. San Francisco. Second Edition.

Hadawiah. 2005. Strategi Memenangkan Persaingan dalam Pemasaran Surat Kabar Harian di Makassar Kasus Fajar, Tribun Timur dan Pedoman Rakyat. Tesis. Program Studi Ilmu Komunikasi Pasca Sarjana Universitas Hasanuddin, Makasar.

Hamka dan Tim Penyusun Kementerian Agama. 2012. Panduan Organisasi Pengelola Zakat. Jakarta. Kementerian Agama RI.

Hendrani, Fransisca Ika. 2007. Analisa penerapan strategi komunikasi pemasaran Aksara Record dalam upaya membangun ekuitas merek. Tesis. Fakultas Ekonomi dan Bisnis Universitas Indonesia. Jakarta

Holt, Rinehart and Winston, Inc. New York-Chicago-San FranciscoToronto-London. The Third Edition. 
Kotler, Philip, Manajemen Pemasaran, jilid 2, Pnj. Hendra Teguh dan Ronny

Antonius Rusly Jakarta: PT Prenhallindo, 1998.

Liliweri, Alo, Komunikasi Serba Ada Serba Makna Jakarta: Kencana, 2011.

Ma'arif, Bambang S., Komunikasi Dakwah Paradigma untuk Aksi (Bandung: PT Remaja Rosdakarya, 2010).

Mulyana, Deddy. 2008. Komunikasi Efektif Suatu Pendekatan Lintas Budaya. Bandung. PT Remaja Rosda Karya.

Neuman. 2004. Social Research Method, Qualitative and Quantitative Approach. The MacMillan Publishing, Co. New York. Second Edition.

Nurbaity Lubis, Arlina. Strategi Pemasaran Dalam Persaingan Bisnis. Jurnal Manajemen. Universitas Sumatera Utara, 2014, hal. 5.

Osgood, Clack E and P.H. Tannebaum. 1977. The Measurement of Meaning. Urbana University of Illinoes Press. The Fourth Edition.

Rogers, Everett M and Rekha Agrawala Rogers. 1993. Commubication In Organizations. The Free Press. A Division of MacMillan Publishing Co, Inc.New York. The Fourth Edition.
Schramm, Wilbur and Daniel Lerner. 1996. Communication and Change. The Last Ten Years and The Next. An-East-West Center Book. The University Press of Hawai. Honolulu. The Third Edition.

Schramm, Wilbur and Kinchaid. 1995. Communication for Development in a Global Perspective Communication and Change. The University Press of Hawai. Honolulu. The Second Edition.

Strauss, Aselm. 1992. Qualitative Analysis for Social Scientist. Cambridge University Press and The MacMillan Publishing Co. New York. The Third Edition.

Suryadi, Risalah Zakat, Jakarta: LAZ BSM Umat, 2002

Taufiqullah. 2004. Zakat Pemberdayaan Ekonomi Umat. Bandung. BAZ Jabar.

Tubbs, Wright W and Ronald F. Mos. 1995. Communication and Communication System. John Wily \& Sons. New York. The Fourth Edition.

Qardawi yusuf. 2002. Hukum Zakat. Jakarta. Pustaka setia antarnusa. Cet ke 6.

Yayat Hidayat. 2008. Zakat Profesi Solusi Mengentaskan Kemiskinan Umat, Penerbit Mulia Press, Bandung. 